\title{
Peningkatan Kemampuan Berfikir Kritis Mahasiswa Tadris IPA Melalui Pendekatan Saintifik Pada Mata kuliah IPA Terpadu
}

\author{
Raden Gamal Tamrin Kusumah ${ }^{1}$ \\ ${ }^{1}$ Science Education Departmen, Institut Agama Islam Negeri Bengkulu, Indonesia \\ Coressponding Author. E-mail: \\ ${ }^{1}$ raden@iainbengkulu.ac.id
}

Received: 10 November 2018

Accepted: 16 Desember 2018

Online Published: 13 Januari 2019

\begin{abstract}
Abstrak
Mata kuliah IPA Terpadu di IAIN Bengkulu merupakan mata kuliah baru bagi mahasiswa Tadris IPA. Hal ini dikarenakan pada tahun 2017/2018 baru ada tiga angkatan. Sehingga, hasil belajar mata kuliah ini tidak terlalu baik. Menurut wawancara dengan salah satu mahasiswa, salah satu penyebabnya adalah kesulitan mengintegrasikan komponen kimia, fisika, biologi secara bersamaan pada satu materi tertentu. Lebih spesifiknya, mahasiswa kesulitan untuk menjelaskan satu materi tertentu yang penjabarannya harus dijelaskan secara komprehensif baik dari segi mata kuliah kimia, fisika, biologi. Oleh karena itu, penelitian ini bertujuan untuk melakukan perbaikan pembelajaran dan meningkatkan kemampuan berfikir kritis mahasiswa melalui pendekatan saintifik pada mata kuliah IPA Terpadu. Metode penelitian ini menggunakan penelitan tindakan kelas. Pembelajarannya terdiri dari dua siklus. Setiap siklus terdiri dari beberapa tahapan, yaitu; perencanaan, tindakan, observasi dan refleksi. Teknik pengumpulan data yang digunakan adalah observasi dan tes hasil belajar. Waktu dilakukan pada semester genap tahun akademik 2017/2018. Subjek penelitian adalah mahasiswa program studi Tadris IPA semester dua tahun akademik 2017/2018 yang sedang menempuh matakuliah IPA Terpadu. Hasil penelitian menunjukkan bahwa hasil belajar siswa yang dilakukan selama 2 siklus pembelajaran telah meningkat pada siklus yang ke-dua. Selain itu juga kemampuan berpikir kritis mahasiswa dalam pelaksanaan pembelajaran di matakuliah IPA Terpadu melalui pendekatan saintifik dapat terukur dan telah berhasil berdasarkan indikator keberhasilan.
\end{abstract}

Kata Kunci: Penelitian Tindakan Kelas; Pendekatan Saintifik; Berpikir Kritis; IPA Terpadu

\section{Increasing the Critical Thinking Ability of Tadris IPA Students through a Scientific Approach in Integrated Science Courses}

\begin{abstract}
The Integrated Science course at LAIN Bengkulu is a new subject for Tadris IPA students. This is because in 2017/2018 there were only three generations. So, the learning outcomes of this course are not very good. According to an interview with one of the students, one of the reasons is the difficulty of integrating chemical, physical, biological components simultaneously on one particular material. More specifically, students find it difficult to explain one particular material whose translation must be explained comprehensively both in terms of chemistry, physics, biology courses. Therefore, this study aims to improve learning and improve students' critical thinking skills through a scientific approach to Integrated Science courses. This research method uses classroom action research. Learning consists of two cycles. Each cycle consists of several stages, namely; planning, action, observation and reflection. Data collection techniques used are observation and learning outcomes tests. Time is carried out in the even semester of the 2017/2018 academic year. The research subjects were students of the 2017/2018 academic year Tadris IP A study program who were taking the Integrated Science course. The results showed that student learning outcomes carried out during the 2 learning gycles had increased in the second cycle. In addition, students' critical thinking skills in the implementation of learning in the Integrated Science course through a scientific approach can be measured and bave been successful based on indicators of success.
\end{abstract}

Keywords: Classroom Action Researcb; Scientific Approach; Critical Thinking; Integrated Sciences 


\section{PENDAHULUAN}

Proses pembelajaran yang kebanyakan dilakukan oleh umumnya para dosen adalah dengan menggunakan metode ceramah sehingga lebih berdasarkan kepada teacher centered bukan proses yang mengarah pada student centered. Berdasarkan pengalaman peneliti mengajar di Program Studi Tadris IPA. Diperoleh gambaran kemampuan mahasiswa khususnya dalam melaksanakan perkuliahan menunjukkan fenomena berfikir yang kurang kritis, seperti kurang terampilnya dalam mengidentifikasi informasi, rendahnya kemampuan bertanya, sulitnya mengemukakan ide atau pendapat, sulitnya menyimpulkan informasi dan rendahnya kemampuan mengevaluasi informasi. Fenomena lain yang muncul dari mahasiswa, diantaranya kurang mampu menggali informasi dari berbagai sumber, penguasaan materi hanya mengandalkan materi yang disampaikan oleh dosen.

Fenomena-fenomena tersebut muncul juga dalam perkuliahan IPA Terpadu, yang dalam matakuliah tersebut sangat menuntut kemampuan berfikir kritis mahasiswa. Steven (dalam Zafri 2012:2) memberikan pengertian berpikir kritis yaitu berpikir dengan benar dalam memperoleh pengetahuan yang relevan dan reliabel, berpikir nalar, reflektif, bertanggung jawab, dan mahir berpikir. Seseorang yang berpikir dengan kritis dapat menentukan informasi yang relevan. Berpikir kritis merupakan kemampuan yang harus dilatih pada peserta didik, karena kemampuan tersebut sangat diperlukan dalam kehidupan. Dosen perlu membantu peserta didik atau mahasiswa untuk mengembangkan keterampilan berpikir kritis melalui strategi, dan metode pembelajaran yang mendukung peserta didik untuk belajar secara aktif. Sementara itu Rahmat (2010:1) mengemukakan berpikir kritis (critical thinking) sinonim dengan pengambilan keputusan (decision making), perencanaan strategis (strategic planning), proses ilmiah (scientific process), dan pemecahan masalah (problem solving).

Di dalam mempelajari materi IPA Terpadu, kompetensi dasar yang harus dikuasai mahasiswa adalah kemampuan dan pemahaman calon guru IPA tentang cara berpikir sesuai dengan metode ilmiah, mengintegrasikan berbagai macam mata pelajaran kedalam satu konsep dan membelajarkan IPA kepada siswa sesuai dengan perkembangannya. Guna terpenuhinya kompetensi tersebut maka dibutuhkan kemampuan berfikir kritis.
Permasalahan yang terjadi di dalam proses pembelajaran seperti kurang terampilnya dalam mengidentifikasi informasi, rendahnya kemampuan bertanya, sulitnya mengemukakan ide atau pendapat, sulit menyimpulkan informasi, dan rendahnya kemampuan mengevaluasi informasi apabila tidak diatasi dengan segera, maka akan menimbulkan masalah yang lebih komplek, yang pada akhirnya akan menimbulkan rendahnya kualitas lulusan. Untuk mengatasi permasalah tersebut, peneliti mencoba mengatasi fenomena-fenomena yang berkembang pada perkuliahan dengan melakukan penelitian tindakan kelas berdasarkan pada pendekatan saintifik. Adapun pemilihan tersebut didasari pada tujuan pendekatan saintifik dimana dengan menggunakan pendekatan saintifik dapat meningkatkan kemampuan berfikir kritis, menyelesaikan masalah, membiasakan kemampuan bertanya, dan mampu mengidentifikasi informasi dengan menggunakan berbagai sumber, mampu mengkomunikasikan informasi kepada orang lain berdasarkan pengolahan informasi yang dimilikinya. Sejalan dengan pendapat Hosnan (2014:34) bahwa pendekatan saintifik adalah proses pembelajaran yang dirancang sedemikian rupa agar peserta didik secara aktif mengonstruk konsep, hukum atau prinsip melalui tahapan-tahapan mengamati, merumuskan masalah, merumuskan hipotesis, mengumpulkan data dengan berbagai teknik, menganalisis data, menarik kesimpulan dan mengomunikasi konsep, hukum atau prinsip yang "ditemukan". Hal ini sejalan menurut Daryanto (2014:51) Pendekatan saintifik dimaksudkan untuk memberikan pemahaman kepada peserta didik dalam mengenal, memahami, berbagai materi menggunakan pendekatan ilmiah, bahwa informasi bisa berasal dari mana saja, kapan saja, tidak bergantung pada informasi searah dari pendidik.

Beberapa pembahasan mengenai teori yang mendukung dari penelitian ini adalah sebagai berikut.

\section{Berpikir Kritis}

Berpikir kritis (critical thinking) adalah proses mental untuk menganalisis atau mengevaluasi informasi. Informasi tersebut bisa didapatkan dari hasil pengamatan, pengalaman, akal sehat atau komunikasi. Menurut Fisher, (2008:10) definisi dari berpikir kritis adalah sebagai proses aktif, karena melibatkan tanya jawab dan berpikir tentang pemikiran diri sendiri. Sedangkan Gunawan (2003:177) menyatakan bahwa keterampilan berpikir kritis adalah kemampuan untuk berpikir pada level yang 
kompleks dan menggunakan proses analisis dan evaluasi. Berpikir kritis melibatkan keahlian berpikir induktif seperti mengenali hubungan, manganalisis masalah yang bersifat terbuka, menentukan sebab dan akibat, membuat kesimpulan dan memperhitungkan data yang relevan. Sedang keahlian berpikir deduktif melibatkan kemampuan memecahkan masalah yang bersifat spasial, logis silogisme dan membedakan fakta dan opini. Keahlian berpikir kritis lainnya adalah kemampuan mendeteksi bias, melakukan evaluasi, membandingkan dan mempertentangkan.

Steven dalam Zafri (2012:2) memberikan pengertian berpikir kritis yaitu berpikir dengan benar dalam memperoleh pengetahuan yang relevan dan reliable, berpikir nalar, reflektif, bertanggung jawab, dan mahir berpikir. Seseorang yang berpikir dengan kritis dapat menentukan informasi yang relevan. Berpikir kritis merupakan kemampuan yang harus dilatih pada peserta didik, karena kemampuan tersebut sangat diperlukan dalam kehidupan. Dosen perlu membantu mahasiswa mengembangkan keterampilan berpikir kritis melalui strategi, dan metode pembelajaran yang mendukung mahasiswa untuk belajar secara aktif. Sementara itu Rahmat (2010:1) mengemukakan berpikir kritis (critical thinking) sinonim dengan pengambilan keputusan (decision making), perencanaan strategis (strategic planning), proses ilmiah (scientific process), dan pemecahan masalah (problem solving).

Dari pendapat para ahli tentang berfikir kritis, maka dapat disimpulkan bahwa berpikir kritis itu meliputi dua langkah besar yakni melakukan proses berpikir nalar (reasoning) dan diikuti dengan pengambilan keputusan/ pemecahan masalah (deciding/problem solving). Dengan demikian dapat pula diartikan bahwa tanpa kemampuan yang memadai dalam hal berpikir nalar (deduktif, induktif dan reflektif), seseorang tidak dapat melakukan proses berpikir kritis secara benar. Berpikir kritis berfokus pada apakah meyakini atau melakukan sesuatu mengandung pengertian bahwa mahasiswa berpikir kritis tidak hanya percaya begitu saja apa yang dijelaskan oleh dosen. mahasisiswa berusaha mempertimbangkan penalarannya dan mencari informasi lain untuk memperoleh kebenaran.

\section{Pendekatan Saintifik}

Menurut Hosnan (2014:34) pendekatan saintifik adalah proses pembelajaran yang dirancang sedemikian rupa agar peserta didik secara aktif mengonstruk konsep, hukum atau prinsip melalui tahapan-tahapan mengamati, merumuskan masalah, merumuskan hipotesis, mengumpulkan data dengan berbagai teknik, menganalisis data, menarik kesimpulan dan mengomunikasi konsep, hukum atau prinsip yang "ditemukan". Hal ini sejalan menurut Daryanto (2014:51) Pendekatan saintifik dimaksudkan untuk memberikan pemahaman kepada peserta didik dalam mengenal, memahami, berbagai materi menggunakan pendekatan ilmiah, bahwa informasi bisa berasal dari mana saja, kapan saja, tidak bergantung pada informasi searah dari guru. Jadi berdasarkan pendapat ahli tersebeut dapat disimpulkan bahwa pendekatan saintifik adalah proses yang mendukung keaktifan mahasiswa untuk berfikir kritis melalui tahapan-tahapan mengamati, menanya, mengumpulkan informasi, menalar, dan mengkomunikasikan.

Sintaksis dalam pendekatan saintifik terdapat 6 langkah. Langkah tersebut adalah 1). Mengamat 2). Menanya 3). Menalar 4). Mencoba 5) Menganalisis data dan menyimpulkan 6). Mengkomunikasikan. Sintaksis ini menjadi istimewa karena langkah mengkomunikasikan melatih siswa untuk menuangkan kembali pengalaman belajarnya kepada khalayak ramai. Baik itu komunikasi secara tulisan melalui publikasi dan tes hasil belajar, maupun lisan melalui diskusi tanya jawab dan lain-lain.

\section{METODE}

\section{Subyek dan Tempat Penelitian}

Kegiatan penelitian ini dilakukan kelas semester dua Tadris IPA tahun ajaran 2017/2018. Pelaksanaan kegiatan penelitian dilakukan dalam 2 siklus pembelajaran. Pada siklus ke-2 siklus pembelajaran hasil belajar mahasiswa meningkat jika dibandingkan dengan pada siklus ke-1. Subjek penelitian adalah mahasiswa Tadris IPA semester 2 berjumlah 34 orang. Mahasiswa ini merupakan mahasiswa terpilih karena pada kelas inilah mahasiswa tersebut mendapatkan mata kuliah IPA terpadu. Mahasiswa dituntut untuk dapat mengintegrasikan berbagai macam mata kuliah IPA menjadi satu kesatuan yang integrative tanpa dikotomi antara satu dengan yang lainnya.

Penelitian ini menggunakan metode penelitian tindakan kelas (classroom action research). Menurut Asrori (2007:13), penelitian tindakan kelas adalah penelitian yang mengkombinasikan prosedur penelitian dengan tindakan substantif, penelitian tindakan kelas ditandai dengan adanya perbaikan terus menerus sehingga tercapai sasaran dari penelitian tersebut. 
Dalam hal ini PTK memiliki karakter penting yang harus dimiliki yaitu permasalahan PTK harus selalu berangkat dari persoalan praktik pembelajaran sehari-hari yang dihadapi oleh pendidik.

Menurut Wardhani, dkk (2003:21) "penelitian tindakan kelas (classroom action research) yaitu penelitian yang bersifat kolaboratif yang dilaksanakan dengan mengikuti prosedur yang menyatakan bahwa dalam satu Siklus terdiri atas empat langkah:perencanaan (planning), pelaksanaan (acting), observasi (observing), dan refleksi (reflecting)". Berdasarkan pendapat di atas, metode penelitian tindakan kelas sesuai dengan tujuan penelitian yang akan dicapai.

Penelitian tindakan kelas adalah penelitian tindakan dalam bidang pendidikan yang dilaksanakan dalam kawasan kelas dengan tujuan untuk memperbaiki dan meningkatkan kualitas belajar. Menurut Kemmis dan Mc'Taggart dalam Arikunto (2006) bahwa penulisan tindakan kelas adalah suatu siklus yang terdiri dari perencanaan, pelaksanaan tindakan, pengamatan, dan refleksi.

Penelitian ini dilaksanakan dengan menggunakan model Kemmis dan Mc'Taggart. (a) Tahap Perencanaan yakni membuat rencana secara keseluruhan berdasarkan pada temuan awal yakni berupaya untuk memperbaiki kualitas proses pembelajaran melalui model pembelajaran berbasis proyek yang akan digunakan dalam matakuliah bermain dan permainan, meliputi tugas-tugas yang akan dilakukan pada setiap siklus selama penelitian, (b)
Tahap Pelaksanaan Tindakan, yakni melaksanakan rencana yang sudah disusun bersama tim dengan dukungan bahan dan media yang sudah disiapkan. Semua tindakan baik pada siklus 1 dan siklus 2 diimplementasikan pada satu kelas pelaksana tindakan adalah peneliti dan dibantu oleh dua orang guru sebagai fasilitator. (c) Tahap Pengamatan Tahap ini dilakukan bersamaan dengan implementasi tindakan. Pada tahap ini dilakukan observasi terhadap berlangsungnya tindakan dan efek yang ditimbulkan oleh tindakan tersebut, baik oleh mahasiswa atau dosen maupun sistem pembelajaran secara keseluruhan. Observasi dilakukan oleh kolabolator (anggota team teaching) dan juga oleh peneliti langsung pada saat melaksanakan pembelajaran (d) Tahap Refleksi Tahap ini merupakan tahap evaluasi dan refleksi terhadap hasil monitoring yang telah dilakukan, baik proses maupun produk pembelajaran, didiskusikan bersama dengan tim peneliti secara objektif dan terbuka seperti komentar, tanggapan, dan penilaian diintegrasikan guna mengukur keberhasilan pelaksanaan pembelajaran, pada siklus pertama, baik yang berhubungan dengan strategi pembelajaran, maupun konten pembelajaran (bidang pengembangan), selanjutnya disimpulkan tingkat keberhasilannya. Bila belum sampai pada tingkat keberhasilan yang diinginkan, maka dicari penyebabnya, kemudian diadakan perbaikan dan tindak lanjut pada siklus berikutnya, dan seterusnya. Tabel 1 disajikan tahapan penelitian model Kemmis Dan Taggart.

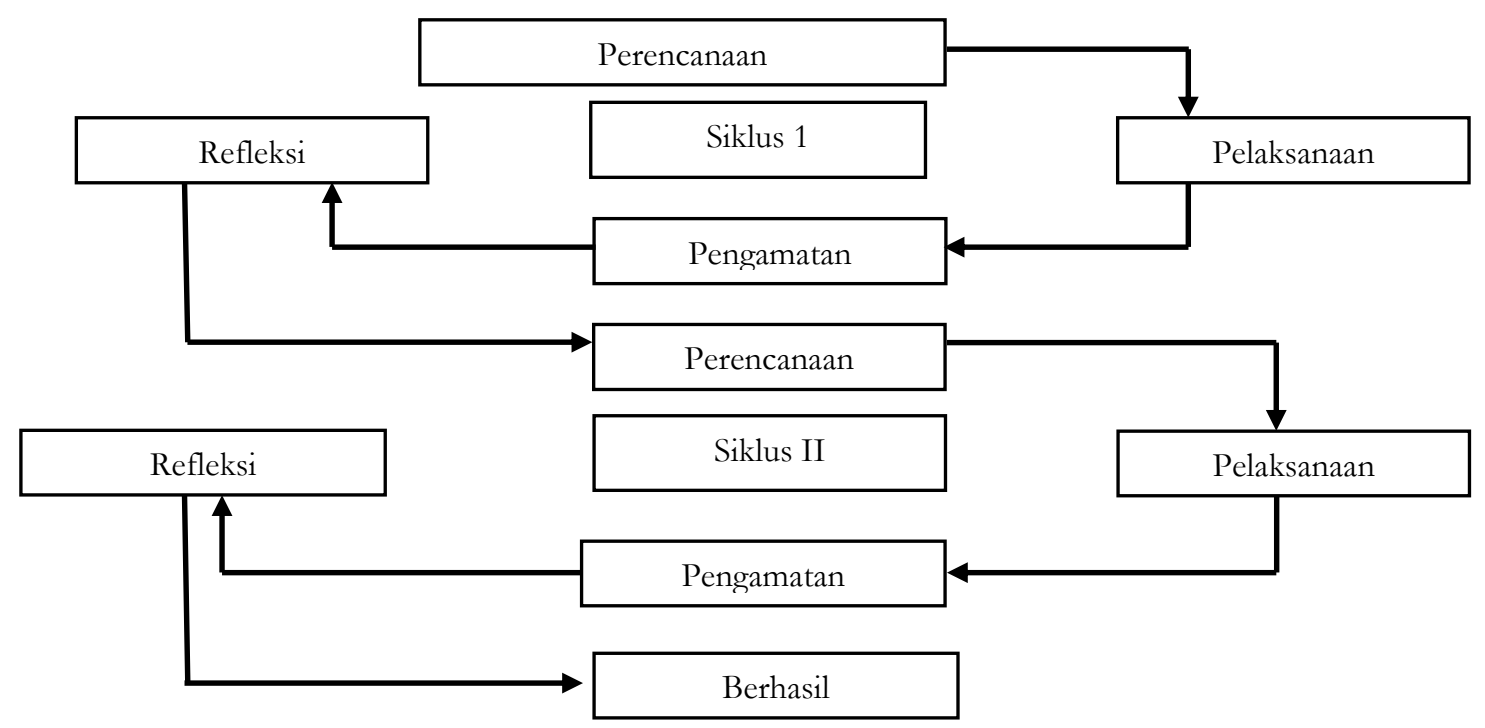

Gambar 1. Diagram Tahap Penelitian Model Kemmis Dan McTaggart 
Penelitian tindakan kelas yang dilakukan pada penelitian ini menggunakan skema diagram yang digunakan oleh Kemmis dan McTaggart yang tercantum pada gambar 1.

Penelitian ini selain menggunakan metode penelitian tindakan kelas juga menggunakan pendekatan penelitian. Secara pengertian, pendekatan penelitian merupakan merupakan cara berpikir yang diadopsi peneliti tentang bagaimana desain riset dibuat dan bagaimana penelitian akan dilakukan. Dalam riset sosial, pendekatan penelitian meliputi tiga jenis, yaitu kualitatif, kuantitaif, dan campuran atau gabungan yang juga dikenal dengan istilah mix method. Proses analisis data dengan pendekatan salah satu dari ketiganya bisa induktif, deduktif atau gabungan keduanya.

Pendekatan kuantitatif yang dimaksudkan adalah yang didefinisikan sebagai cara pandang peneliti dengan mengadopsi desain penelitian kuantitatif. Kita juga akan melihat karakteristiknya untuk memahami definisinya. Karakteristik desain penelitian kuantitatif meliputi fokus riset yang lebih terperinci, kaku, statis, dan prosesnya sesuai alur yang sudah disusun sejak awal dan tidak dapat diubah. Kematangan dalam perencanaan adalah kuncinya.

Pendekatan penelitian kuantitatif yang diterapkan secara langsung dapat memberitahu kita bahwa pendekatan penelitian yang diterapkan adalah kuantitatif. Namun perlu dicatat bahwa ketika kita menemukan aplikasi metode kuantitatif dalam laporan riset, belum tentu pendekatannya kuantitatif. Bisa jadi, pendekatan penelitian yang digunakan adalah gabungan atau campuran antara kuantitatif dan kualitatif seperti yang akan dijelaskan nanti.

Pendekatan penelitian bisa diidentifikasi dari keseluruhan aspek penelitian yang digunakan. Dalam aspek tujuan, pendekatan kuantitatif memiliki karakteristik antara lain; dimaksudkan untuk menjelaskan hubungan antarvariabel penelitian, menguji hipotesis atau teori, dan melakukan generalisasi fenomena sosial yang diteliti.

Dari aspek pengumpulan datanya, pendekatan kuantitatif menggunakan cara survey atau wawancara terstruktur. Sesuai metode pengumpulan datanya, maka instrumen yang sering digunakan antara lain kuesioner atau angket, buku tes, dan sebagainya. Pendekatan kuantitatif menggunakan perpaduan anatara ilmu sosial dan ilmu statistik dalam analisis datanya.

Riset pendidikan yang menggunakan pendekatan kuantitatif umumnya bersifat induktif. Analisis induktif artinya gambaran besar yang berupa hipotesis atau teori diuji kebenarannya dengan proses pengujian variabel yang lebih detail. Jika hipotesis ditolak, maka peneliti menemukan hipotesis baru berupa penjelasan tentang hubungan antar variabel yang bisa diterima.

Pendekatan penelitian yang digunakan dalam penelitian ini adalah pendekatan penelitian kuantitatif. Pendekatan ini dilakukan karena dalam proses pelaksanaan dan dalam proses analisis data yang telah diperoleh merupakan data kuantitatif. Artinya data-data tersebut merupakan data-data angka. Data-data tersebut bisa berupa data hasil belajar, data hasil penerapan penerapan strategi penelitian berupa pendekatan saintifik. Data-data itu diterjemahkan dan diolah dengan menggunakan aplikasi statistik, dalam hal ini menggunakan aplikasi SPSS. Dari data variabelvariabel tersebut akan diolah sehingga ditemukan hubungan dari masing-masing variabel. Jika variabel pengaruh dapat mempengaruhi variabel terikat, maka penelitian tindakan kelas ini dapat dikatakan berhasil.

Penelitian tindakan kelas kebanyakan menggunakan pendekatan kuantitatif dalam setiap penelitiannya. Hal ini dilakukan karena penelitian tersebut banyak sekali menggunakan data statistik. Pengolahan data statistiknya tersebut menggunakan statistik deskriptif dan statistik inferensial. Statistik deskriptif merupakan statistika yang menampilkan dan mendeskripsikan data-data hasil penelitian secara apa adanya, contohnya berupa rekapan, dimanifestasikan dalam pie chart dan lain-lain. Sedangkan pengolahan statistika inferensial adalah pengolahan data statistika yang menghubungkan data antara satu variabel dengan variabel yang lain.

Pendekatan penelitian yang dilakukan ini sesuai dengan pendapat (Arikunto 2006: 12) yang mengemukakan penelitian kuantitatif adalah pendekatan penelitian yang banyak dituntut menguakan angka, mulai dari pengumpulan data, penafsiran terhadap data tersebut, serta penampilan hasilnya.

Teknik pengumpulan data dalam penelitian ini berdasarkan data yang terkait dengan aktivitas kemampuan berpikir kritis mahasiswa dengan menggunakan pendekatan saintifik. Sumber datanya adalah:

\section{a. Lembaran observasi}

Digunakan untuk mengamati kemampuan berpikir kritis mahasiswa dalam interaksi pembelajaran IPA Terpadu dalam pembelajaran 
sesuai dengan indikator yang ditetapkan pada setiap siklus dalam proses pembelajaran. Data ini didapat dengan lembar pengamatan yaitu catatan tertulis tentang apa yang didengar, dilihat, dan dialami mahasiswa dalam rangka pengumpulan data.

b. Catatan lapangan

Digunakan sebagai sumber yang sangat penting dalam penelitian karena catatan lapangan merupakan catatan tertulis tentang apa yang didengar, dilihat, diamati, dan dipikirkan dalam rangka mengumpulkan data dan refleksi data.

c. Dokumentas video dan foto
Digunakan untuk memperoleh data obyek penulisan sebelum dilakukan tindakan ataupun sesudah dilakukan tindakan.

Instrumen penelitian yang digunakan adalah berupa instrumen tes hasil belajar. Sebelum digunakan tes terlebih dahulu digunakan kisi-kisi. Kisi-kisi yang digunakan berupa kisi-kisi kemampuan berpikir kritis dan kisi-kisi penerapan pendekatan saintifik. Kisi-kisi instrumen penelitian tersebut dapat dilihat pada tabel 1 dan tabel 2.

Tabel 1. Kisi-kisi Kemampuan Berpikir Kritis

\begin{tabular}{|c|c|c|}
\hline No & Aspek & Indikator \\
\hline \multirow[t]{3}{*}{1} & \multirow{3}{*}{$\begin{array}{l}\text { Memberikan } \\
\text { sederhana }\end{array}$} & Memfokuskan pertanyaan \\
\hline & & Menganalisis argumen \\
\hline & & Bertanya dan menjawab pertanyaan \\
\hline \multirow[t]{2}{*}{2} & \multirow{2}{*}{$\begin{array}{l}\text { Membangun } \\
\text { dasar }\end{array}$} & Mempertimbangkan apakah sumber dapat dipercaya atau tidak \\
\hline & & Mengobservasi dan mempertimbangkan hasil observasi \\
\hline 3 & Menyimpulkan & Membuat dan menentukan hasil pertimbangan \\
\hline \multirow[t]{2}{*}{4} & \multirow[t]{2}{*}{ Memberikan penjelasan lanjut } & Mendefinisikan istilah dan mem-pertimbangkan suatu definisi \\
\hline & & Mendefinisikan asumsi-asumsi \\
\hline \multirow[t]{2}{*}{5} & \multirow[t]{2}{*}{ Mengatur strategi dan taktik } & Menentukan suatu tindakan \\
\hline & & Berinteraksi dengan orang lain \\
\hline
\end{tabular}

Tabel 2. Kisi-kisi Penerapan Pendekatan Saintifik

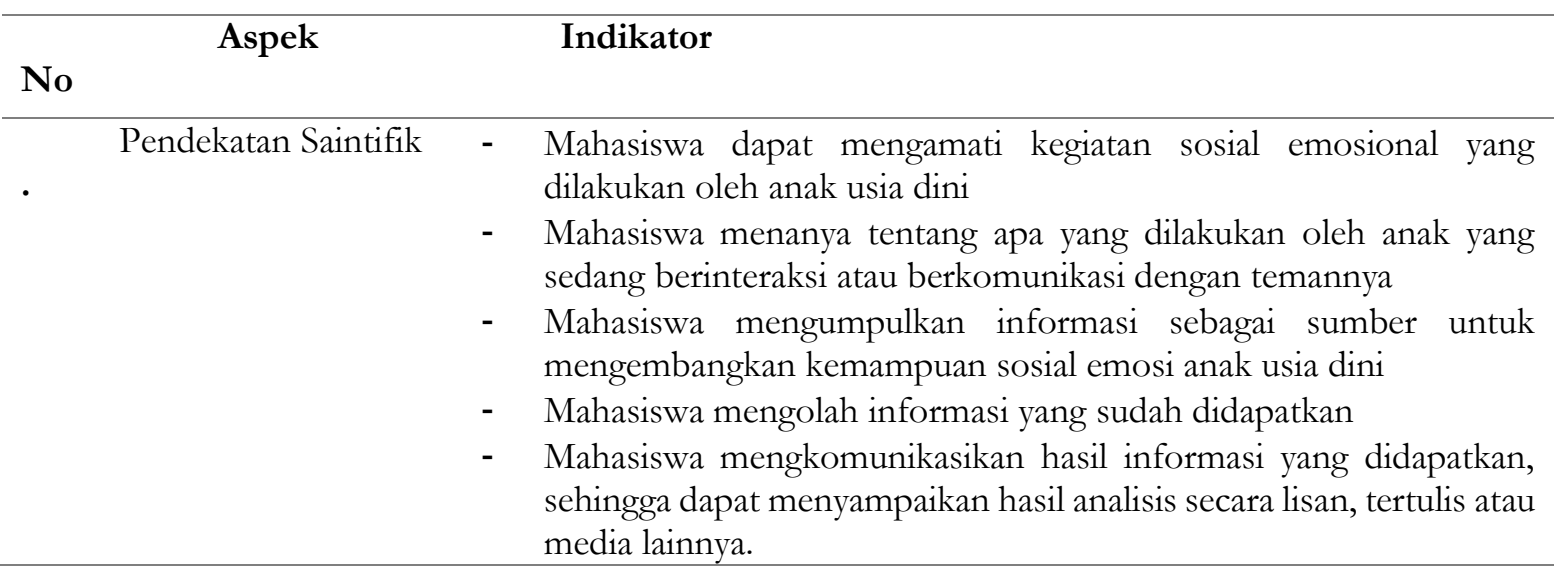

\section{Teknik Analisis Data}

Data hasil observasi adalah data pendukung dalam penelitian ini. Data hasil observasi ini disajikan dalam bentuk tabel dengan tujuan untuk mempermudah dalam membaca data. Selanjutnya data tersebut dianalisis dengan menggunakan penghitungan persentase dengan rumus:

$$
\begin{gathered}
\% \text { skor rata }- \text { rata }=\frac{\sum \text { skor yang diperoleh }}{\text { skor maksimal }} \times 100 \% \\
\text { (Mahyuni dalam Asnati, 2014: 40) }
\end{gathered}
$$

Kemudian hasil perhitungan tersebut diklasifikasikan menjadi kriteria keberhasilan peserta didik seperti pada tabel 3 berikut ini : 
Tabel 3. Interval Kemampuan Berpikir Kritis Peserta Didik

\begin{tabular}{|l|l|l|}
\hline No & Interval & Interpretasi Penilaian \\
\hline \hline 1 & $12-21$ & Sangat Kurang \\
\hline 2 & $22-31$ & Kurang \\
\hline 3 & $32-40$ & Baik \\
\hline 4 & $41-50$ & Sangat Baik \\
\hline \multicolumn{3}{|c|}{ Analisis data yang dilakukan dalam }
\end{tabular}

penelitian ini adalah sebagai berikut: data tentang keaktifan mahasiswa dalam pembelajaran diolah dengan presentase, untuk mengolah hasil belajar mahasiswa digunakan ketuntasan belajar. Langkah ini juga digunakan oleh Kusumah \& Munandar (2017) untuk penelitiannya. Sedangkan untuk mengetahui efektivitas antar siklus diolah dengan t-tes. Adapun rumusnya adalah sebagai berikut :

$$
t=\frac{\bar{X}_{1}-\bar{X}_{2}}{\sqrt{\frac{\left(n_{1}-1\right) S_{1}^{2}+\left(n_{2}-1\right) S_{2}^{2}}{n_{1}+n_{2}-2}\left(\frac{1}{n_{1}}+\frac{1}{n_{2}}\right)}}
$$

\section{Indikator Keberhasilan}

Indikator keberhasilan dalam penelitian tindakan ini adalah :

1. Perhitungan peningkatan antar siklus dapat dikatakan berhasil apabila pada siklus dua lebih baik dari pada siklus 1 dan siklus tiga lebih baik dari siklus dua dibuktikan dengan hasil t-tes.

2. Ketuntasan yang dicapai oleh mahasiswa secara klasikal, dicapai apabila daya serap klasikal mencapai minimal $80 \%$

3. Ketuntasan yang dicapai oleh mahasiswa secara individual, apabila daya serap yang dicapai mahasiswa mencapai $75 \%$

\section{HASIL DAN PEMBAHASAN}

\section{Hasil}

Berdasarkan hasil analisis studi pendahuluan yang dilaksanakan, mata kuliah IPA Terpadu dalam Pembelajaran, selama 1 semester terakhir ini ditemui beberapa indikator yang menunjukkan adanya masalah dalam pelaksanaan pembelajaran, antara lain kurangnya kemauan untuk menggali materi perkuliahan dari sumber lain, atau hanya mengandalkan materi yang disajikan oleh dosen, hanya $10 \%$ mahasiswa yang aktif bertanya, menunjukkan rasa ingin tahu, dan kurangnya kesungguhan dalam mengerjakan tugas yang diberikan. Seperti pada pembelajaran yang telah dilakukan, dari 36 orang mahasiswa yang diberikan tugas, yang sungguh-sungguh mengerjakan tugas dengan kreatif dan tepat waktu hanya 20 orang (31\%), sedangkan selebihnya bervariasi ada yang terlambat, mengerjakan tugas alakadarnya, bahkan ada 2 orang $(7 \%)$ yang copypaste dari tugas temannya, dan terdapat penyimpangan-penyimpangan perilaku lainnya yang menunjukkan lemahnya kualitas proses pembelajaran. Atas dasar itu diperlukan adanya strategi pembelajaran yang dapat meningkatkan kualitas proses, menantang mahasiswa untuk terlibat aktif dalam pembelajaran dan mendapatkan pengalaman belajar yang bermakna bagi mereka dalam melaksanakan tugasnya di kemudian hari.

Oleh karena itu dalam penelitian ini memilih pendekatan saintifik sebagai langkah yang tepat, karena pembelajaran untuk memberikan pemahaman kepada mahasiswa dalam mengenal, memahami, berbagai materi menggunakan pendekatan ilmiah. Dengan menggunakan pendekatan saintifik, memberikan kesempatan kepada mahasiswa untuk terlibat secara aktif dalam pembelajaran di kelas, melalui tahapan-tahapan mengamati, menanya, mengumpulkan informasi, menalar, dan mengkomunikasikan. Berdasarkan analisis dari permasalahan yang dikemukakan tersebut maka dibuat perencanaan tindakan.

\section{Deskripsi siklus 1}

\section{a. Tahap Perencanaan (General Plan)}

Perencanaan secara umum pada siklus 1 berkaitan dengan materi cara kerja otak manusia, peran dan fungsi dalam kehidupan yang dibahas selama tiga kali pertemuan.

Kompetensi dasar yang ingin dicapai adalah setelah menyelesaikan seluruh materi perkuliahan ini, diharapkan mahasiswa memperoleh pengetahuan dan pemahaman tentang otak/sistem syaraf, dan cara menstimulasinya dengan tepat sesuai dengan tahap perkembangan anak usia dini.

Indikator Mahasiswa mampu menjelaskan otak manusia meliputi (a) Pengertian otak manusia, (b) Fungsi otak, (c) Fungsi otak kanan, (d) Fungsi otak kiri, dan (e) Peranan otak bagi manusia.

Materi Perkuliahan yaitu (1) Nilai Karakter : Tanggung jawab, kreativitas, disiplin, kerja keras, ketekunan, kerjasama, mengembangkan toleransi dalam kerja kelompok. (2) Materi Pokok : Pengertian, fungsi, peranan otak bagi manusia.

\section{b. Tahap Implementasi Tindakan (Implementasi Action)}

Dalam tahapan ini, peneliti bersama supervisor melaksanakan pembelajaran melalui 
penerapan pendekatan saintifik di kelas III A. Perkuliahan diawali dengan memaparkan silabus mata kuliah IPA Terpadu dalam Pembelajaran dan menjelaskan strategi pembelajaran yang akan digunakan dalam mengikuti perkuliahan selama satu semester dengan menggunakan pendekatan saintifik, dan menuntut mahasiswa untuk mengembangkan kemampuan berpikir kritis, dalam proses pembelajaran berlangsung kegiatankegiatan sebagai berikut dengan tiga tahapan, yaitu pendahuluan, inti, dan penutup. Materi yang diberikan pada siklus I adalah cara kerja otak. Proses pembelajaran sebagai berikut:

1) Mengamati, dosen memberikan suatu permasalahan yang berkaitan dengan materi perkuliahan, "Bagaimana cara kerja otak manusia", mahasiswa dibagi 5 kelompok yang terdiri dari 7 orang. Secara kelompok mahasiswa mengamati dan mendiskusikan bagaimana cara kerja otak manusia.

2) Menanya, mahasiswa mulai merumuskan pertanyaan-pertanyaan yang berkaitan tentang cara kerja otak.

3) Mencoba, setiap mahasiswa dalam kelompok mencoba untuk mencari penyelesaian dalam memecahkan masalah berkaitan dengan cara kerja otak, melalui berbagai macam sumber, baik dari buku, media cetak, media elektronik, maupun video dan mengerjakan secara cermat dan teliti kegiatan di dalam kelas.

4) Menalar, selanjutnya setiap kelompok mendiskusikan hasil kerja masing-masing, untuk menganalisis hasil kerja kelompok.

5) Mengkomunikasikan, perwakilan setiap kelompok mempersentasikan hasil diskusi kelompok di depan kelas (share), dengan penuh percaya diri, dan anggota kelompok lain diminta menanggapi dengan penuh rasa tanggung jawab. Mahasiswa saling berinteraksi dengan melakukan tanya jawab antar kelompok.

Kegiatan penutup dilakukan dengan memberikan penguatan kembali kepada mahasiswa. Dosen menyimpulkan materi perkuliahan dan mahasiswa diberikan soal latihan atas materi yang telah dipelajari dari pertemuan pertama sampai pertemuan ketiga.

\section{c. Tahap Monitoring Implemetasi dan Efek (Monitor Implementation $\boldsymbol{\&}$ Effects)}

Pelaksanaan monitoring dilakukan bersamaan dengan pelaksanaan tindakan yakni mengamati kemampuan berfikir kritis mahasiswa saat partisipasi dalam tanya jawab, partisipasi seluruh anggota kelompok dalam melaksanakan diskusi, kemampuan mempresentasikan hasil diskusi, kemampuan dan kelancaran dalam menanggapi permasalahan/pertanyaanpertanyaan yang diajukan saat mempresentasikan hasil diskusi, ketepatan menjawab pertanyaan, kemampuan menuangkan gagasan secara tertulis, dan keaslian gagasannya. Dalam pelaksanaan pembelajaran ternyata belum semua kelompok dapat menampilkan semua aspek seperti yang diharapkan, melainkan masih bervariasi seperti pada saat melakuan diskusi terdapat 5 kelompok yang sudah dapat bekerjasama dengan baik, aktif, tertib, sedangkan 3 kelompok masih didominasi oleh 3 orang, sedangkan 2 anggota yang lainnya belum dapat terlibat secara aktif. Pada saat mempresentasikan hasil tugas, kemampuan menyampaikan dan menanggapi pertanyaan dari kelompok lain, masih belum merata, yang menguasai dan berani menjawab rata-rata 2-3 orang, begitupun untuk aspek menuangkan gagasan/ide dan ketepatan menjawab pertanyaan.

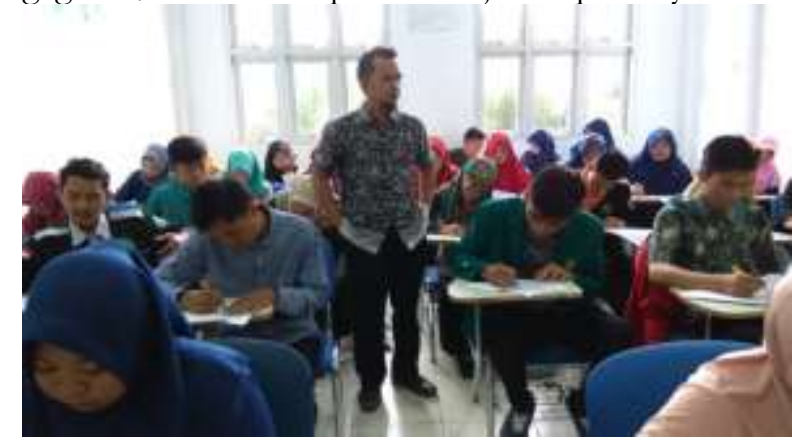

Gambar 2. Suasana mahasiswa yang sedang tes hasil belajar untuk mengetahui hasil penelitian tindakan kelas yang telah dilakukan

Adapun hasil monitoring secara lengkap dapat disajikan dalam tabel 4 
Tabel 4. Kemampuan berpikir kritis mahasiswa pada Siklus 1

\begin{tabular}{|l|l|l|l|l|l|l|l|l|l|}
\hline \multirow{2}{*}{ No } & \multirow{2}{*}{ Aspek yang diamati } & \multicolumn{3}{|c|}{ A } & \multicolumn{3}{|c|}{ B } & \multicolumn{3}{c|}{ C } & \multicolumn{3}{c|}{ D } \\
\cline { 4 - 13 } & & F & $\%$ & F & $\%$ & F & $\%$ & F & $\%$ \\
\hline 1. & Mampu memfokuskan pertanyaan & 5 & 14 & 15 & 42 & 8 & 22 & 8 & 22 \\
\hline 2. & $\begin{array}{l}\text { Mampu menjawab pertanyaan/memberikan } \\
\text { argumen berdasarkan sumber }\end{array}$ & 7 & 19 & 18 & 50 & 4 & 11 & 2 & 20 \\
\hline 3. & $\begin{array}{l}\text { Mampu menganalisis argumen } \\
\text { Mampu menyimpulkan temuan/konsep } \\
\text { berdasarkan sumber }\end{array}$ & 5 & 25 & 16 & 44 & 10 & 28 & 1 & 3 \\
\hline 4. & $\begin{array}{l}\text { Mampu mempresentasikan hasil } \\
\text { observasi/temuan }\end{array}$ & 10 & 28 & 10 & 28 & 6 & 17 & 10 & 28 \\
\hline 5. & $\begin{array}{l}\text { Mampu berinteraksi dalam kelompok untuk } \\
\text { memecahkan masalah }\end{array}$ & 8 & 22 & 14 & 39 & 6 & 17 & 10 & 28 \\
\hline 6. & N 36 & & & & & & & & \\
\hline
\end{tabular}

Berdasarkan Tabel 4 tergambar bahwa kemampuan berfikir kritis mahasiswa secara klasikal pada aspek kemampuan memfokuskan pertanyaan kategori Sangat Baik 5 orang (14\%), kategori Baik 15 orang (42\%), kategori Cukup 8 orang $(22 \%)$ dan kategori Kurang berjumlah 8 $(22 \%)$ orang mahasiwa. Aspek menjawab pertanyaan/memberikan argumen berdasarkan sumber, mahasiswa yang termasuk kategori Sangat Baik adalah 7 orang (14\%), kategori Baik 18 orang $(50 \%)$, kategori Cukup 4 orang (12\%). Kemampuan mahasiswa pada aspek menganalisis argumen, mahasiswa yang menunjukkan kategori Sangat Baik terdapat 5 orang (14\%), kategori Baik 12 orang $(33 \%)$, kategori Cukup 13 orang $(36 \%)$ dan kategori Kurang 4 orang (12\%). Aspek menyimpulkan temuan/konsep berdasarkan sumber, yang termasuk kategori Sangat Baik 9 orang (25\%), kategori Baik 16 orang (44\%), kategori Cukup 10 orang (23\%) dan yang kategori Kurang 1 orang (3\%). Aspek mempersentasikan hasil observasi/temuan yang termasuk kategori Sangat Baik terdapat 10 orang (28\%), kategori Baik 10 orang (28\%), kategori Cukup 6 orang $(17 \%)$ kategori Kurang ada 10 orang (28\%), sedangkan aspek berinteraksi dalam kelompok untuk memecahkan masalah, yang kategori Sangat Baik terdapat 8 orang $(22 \%)$, kategori Baik 14 orang (39\%), kategori Cukup 6 orang (17\%) dan kategori Kurang 10 orang $(28 \%)$.

Pengamatan yang dilakukan selama penelitian, selain proses pembelajaran juga diperoleh hasil pengamatan yang berkaitan dengan hasil belajar yang memiliki rata-rata $(78,80)$.

\section{d. Tahap Penjelasan Kegagalan (Reconnaissance Explain Any Failure to Implement And Effect)}

Berdasarkan hasil monitoring pembelajaran, tim peneliti mengevaluasi kegiatan pembelajaran yang telah dilakukan baik proses maupun hasil, kemudian menganalisis setiap langkah pembelajaran sebagai kegiatan refleksi. Berdasarkan kegiatan refleksi masih ditemui kelemahan-kelemahan yang didiskusikan untuk mendapat solusinya.

Adapun hasil refleksi tersebut adalah :

1) Kemampuan dalam menuangkan gagasan pada saat penyelesaian masalah, hanya dua kelompok yang sudah baik, sedangkan 3 kelompok masih perlu mendapat bimbingan yang intensif.

2) Rendahnya kemampuan dan kemauan bertanya mahasiswa dalam pembelajaran

3) Pengalaman belajar yang diperoleh masih rendah, terutama dalam menggali berbagai sumber.

4) Kemampuan melaporkan hasil diskusi kelompok secara tertulis, belum mengikuti kaidah-kaidah penulisan ilmiah.

Berdasarkan hasil refleksi pembelajaran tersebut, tim peneliti mengadakan diskusi untuk terus berupaya mencari solusi bagi kelompok yang masih mengalami kesulitan. Solusi yang terus menerus dilakukan yaitu memotivasi dan memahamkan untuk mengembangkan pengalaman yang memupuk kemampuan menuangkan ide, dan kemampuan menyampaikan ide kepada orang lain, baik secara lisan maupun tertulis dengan memperhatikan kaidah-kaidah karya ilmiah. Secara konkrit solusi yang dilakukan adalah : 
1) Memberikan kesempatan dan tugas kepada kelompok yang belum aktif dalam menuangkan gagasan pada saat penyelesaian masalah

2) Dosen menawarkan reward poin untuk mahasiswa/kelompok yang berhasil dalam kemampuan menyampaikan ide kepada orang lain, baik secara lisan maupun tertulis dengan memperhatikan kaidah-kaidah karya ilmiah

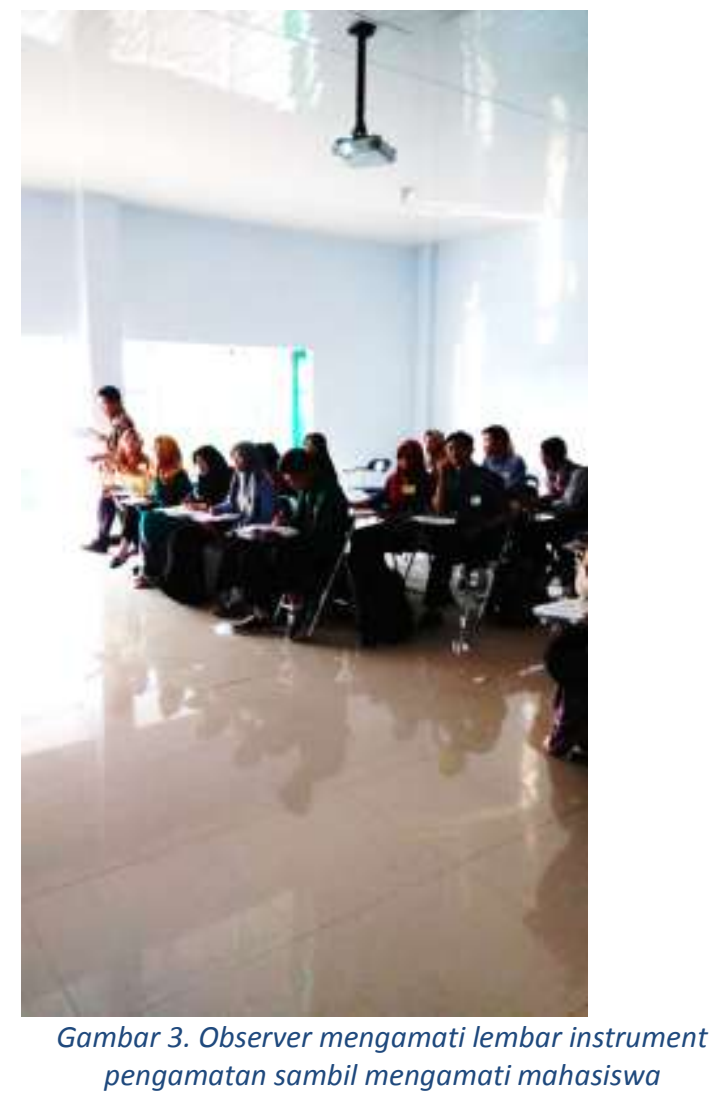

\section{Deskripsi Siklus 2}

a. Tahap Perencanaan (General Plan)

Hasil rekomendasi pada siklus pertama menjadi pertimbangan pokok dalam merencanakan dan melaksanakan tindakan pada siklus 2 . Perencanaan pada siklus ini berkaitan dengan materi Cara Menstimulasi Otak Anak serta Model-model Stimulasinya.

Kompetensi Dasar: Setelah menyelesaikan seluruh materi perkuliahan ini diharapkan mahasiswa mampu menjelaskan cara menstimulasi otak anak dalam pembelajaran anak usia dini.

Indikator yang diharapkan tercapai dalam pertemuan ini adalah mampu mendeskripsikan tentang (1) Jenis-jenis rangsangan, (2) Model stimulasi otak pada anak, (3) Stimulasi dasar, (4) Stimulasi lanjutan, dan (5) Stimulasi khusus.
Materi Pokok: (1) Jenis-jenis rangsangan, (2) Model stimulasi otak pada anak, (3) Stimulasi dasar, (4) Stimulasi lanjutan, dan (5) Stimulasi khusus.

\section{b. Tahap Implementasi Tindakan (Implementasi Action)}

Dalam tahapan ini, peneliti bersama team teaching melaksanakan pembelajaran melalui penerapan pendekatan saintifik di kelas III A. Materi yang diberikan pada siklus 2 adalah Cara Menstimulasi Otak Anak. Adapun proses pembelajaran sebagai berikut:

1) Mengamati, dosen memberikan suatu permasalahan yang berkaitan dengan materi perkuliahan, "Bagaimana cara menstimulasi otak anak". Mahasiswa dibagi 5 kelompok yang terdiri dari 7 orang. Secara kelompok mahasiswa mengamati dan mendiskusikan bagaimana cara kerja otak.

2) Menanya, mahasiswa mulai merumuskan pertanyaan-pertanyaan yang berkaitan tentang cara kerja otak.

3) Mencoba, setiap mahasiswa di dalam kelompok mencoba untuk mencari penyelesaian dalam memecahkan masalah berkaitan dengan cara menstimulasi otak, melalui berbagai macam sumber, baik dari buku, media cetak, media elektronik, maupun video dan mengerjakan secara cermat dan teliti kegiatan di dalam kelas.

4) Menalar, selanjutnya setiap kelompok mendiskusikan hasil kerja masingmasing, untuk menganalisis hasil kerja kelompok.

5) Mengkomunikasikan, perwakilan setiap kelompok mempersentasikan hasil diskusi kelompok di depan kelas (share), dengan penuh percaya diri, dan anggota kelompok lain diminta menanggapi dengan penuh rasa tanggung jawab. Mahasiswa saling berinteraksi dengan melakukan tanya jawab antar kelompok.

Pada kegiatan penutup, dosen memberikan penguatan kembali kepada mahasiswa. Dosen dan mahasiswa menyimpulkan materi perkuliahan kemudian mahasiswa diberikan soal latihan atas materi yang telah dipelajari dari pertemuan pertama sampai pertemuan ketiga.

c. Tahap Monitoring Implemetasi dan Efek (Monitor Implementation $\&$ Effects)

Pelaksanaan monitoring dilakukan bersamaan dengan pelaksanaan tindakan yakni mengamati keaktifan mahasiswa saat partisipasi 
dalam sesi tanya jawab, partisipasi seluruh anggota kelompok dalam melaksanakan diskusi, dan kemampuan mempresentasikan hasil diskusi, serta kemampuan dan kelancaran dalam menanggapi permasalahan/pertanyaanpertanyaan yang diajukan saat mempresentasikan hasil diskusi, ketepatan menjawab pertanyaan, kemampuan menuangkan gagasan secara tertulis, dan keaslian gagasannya. Implementasi dilakukan oleh tim dosen. Adapun hasil monitoring dapat disajikan pada tabel 5 berikut :

Tabel 5. Kemampuan berpikir kritis mahasiswa pada Siklus 2

\begin{tabular}{|c|c|c|c|c|c|c|c|c|c|}
\hline \multirow[b]{2}{*}{ No } & \multirow{2}{*}{ Aspek yang diamati } & \multicolumn{2}{|c|}{$\mathbf{A}$} & \multicolumn{2}{|c|}{$\mathbf{B}$} & \multicolumn{2}{|c|}{ C } & \multicolumn{2}{|c|}{ D } \\
\hline & & $\mathbf{F}$ & $\%$ & $\mathbf{F}$ & $\%$ & $\mathbf{F}$ & $\%$ & $\mathbf{F}$ & $\%$ \\
\hline 1. & Mampu memfokuskan pertanyaan & 8 & 44 & 18 & 50 & 4 & 11 & 6 & 17 \\
\hline 2. & $\begin{array}{l}\text { Mampu menjawab pertanyaan/memberikan } \\
\text { argumen berdasarkan sumber }\end{array}$ & 10 & 28 & 20 & 56 & 4 & 11 & 2 & 6 \\
\hline 3. & Mampu menganalisis argumen & 18 & 50 & 16 & 33 & 2 & 6 & - & - \\
\hline 4. & $\begin{array}{l}\text { Mampu menyimpulkan temuan/konsep } \\
\text { berdasarkan sumber }\end{array}$ & 10 & 28 & 16 & 44 & 10 & 28 & - & - \\
\hline 5. & $\begin{array}{l}\text { Mampu mempresentasikan hasil } \\
\text { observasi/temuan }\end{array}$ & 10 & 28 & 20 & 56 & 6 & 17 & - & - \\
\hline 6. & $\begin{array}{l}\text { Mampu berinteraksi dalam kelompok untuk } \\
\text { memecahkan masalah }\end{array}$ & 8 & 22 & 14 & 39 & 6 & 17 & 10 & 28 \\
\hline & $\mathrm{N}=36$ & & & & & & & & \\
\hline
\end{tabular}

Berdasarkan Tabel 5 menggambarkan bahwa kreativitas berfikir mahasiswa secara klasikal pada aspek kemampuan mengemukakan pendapat dengan lancar yang termasuk kategori Sangat Baik 8 orang (44\%) kategori Baik 18 orang (50\%), kategori Cukup 4 orang mahasiswa $(11 \%)$ dan kategori Kurang berjumlah 6 (17\%) orang mahasiswa. Aspek keluwesan dalam berpendapat pada saat memecahkan suatu masalah, mahasiswa yang termasuk kategori Sangat Baik adalah 10 orang (28\%), kategori Baik 20 orang $(56 \%)$, kategori Cukup 4 orang $(11 \%)$, kategori Kurang terdapat 2 orang (6\%). Kemampuan mahasiswa pada aspek original dalam berpendapat, mahasiswa yang menunjukkan kategori Sangat Baik terdapat 18 orang (50\%). Aspek rasa ingin tahu yang mendapat kategori Sangat Baik 10 orang (28\%), kategori Baik 16 orang (44\%) dan kategori Cukup 6 orang (17\%). Aspek menunjukkan senang bertanya, yang termasuk kategori Sangat Baik 10 orang (28\%), kategori Baik 20 orang (56\%), kategori Cukup 6 orang (17\%). Aspek kemampuan bertanya yang termasuk kategori Sangat Baik terdapat 10 orang (28\%), kategori Baik 20 orang (56\%), kategori Cukup 6 orang $(17 \%)$. Sedangkan aspek selalu mencari pengalaman baru dalam memecahkan masalah, yang kategori Sangat Baik 8 orang $(22 \%)$, kategori Baik 14 orang (39\%), kategori Cukup 6 orang $(17 \%)$ dan kategori Kurang 8 orang $(22 \%)$.

Pengamatan yang dilakukan selama penelitian, selain proses pembelajaran juga diperoleh hasil pengamatan yang berkaitan dengan hasil belajar yang memiliki rata-rata $(84,50)$.

\section{d. Tahap Penjelasan Kegagalan (Reconnaissance Explain Any Failure to Implement And Effect) \\ Berdasarkan hasil monitoring} pembelajaran, tim peneliti mengevaluasi kegiatan pembelajaran yang telah dilakukan baik proses maupun hasil, kemudian menganalisis setiap langkah pembelajaran sebagai kegiatan refleksi. Pada saat memecahkan suatu masalah, beberapa mahasiswa terlihat luwes dalam berpendapat, menunjukkan senang bertanya, dan mencari pengalaman baru dalam memecahkan masalah. Namun demikian, berdasarkan kegiatan refleksi masih ditemui kelemahan-kelemahan yang didiskusikan untuk mendapat solusinya. Adapun hasil refleksi tersebut adalah : 
1) Kemampuan dalam menuangkan gagasan pada saat penyelesaian masalah, masih ada kelompok yang masih mendapat kesulitan.

2) Kemampuan melaporkan hasil diskusi kelompok secara tertulis, belum mengikuti kaidah-kaidah penulisan ilmiah.

Berdasarkan hasil refleksi, pembelajaran tim peneliti mengadakan diskusi untuk terus berupaya mencari solusi bagi kelompok yang masih mengalami kesulitan. Solusi yang terus menerus dilakukan yaitu memotivasi dan memahamkan untuk mengembangkan pengalaman yang memupuk kemampuan menuangkan ide, dan kemampuan menyampaikan ide kepada orang lain, baik secara lisan maupun tertulis dengan memperhatikan kaidah-kaidah karya ilmiah.

\section{KESIMPULAN}

Berdasarkan hasil penelitian dan pembahasan yang telah diuraikan pada bab-bab sebelumnya dapat diambil kesimpulan bahwa:

1. Penerapan pendekatan saintifik dalam pembelajaran untuk meningkatkan kemampuan berfikir kritis mahasiswa Tadris IPA

2. Pendekatan saintifik dalam meningkatkan kemampuan berfikir kritis mahasiswa Tadris IPA dalam pembelajaran di matakuliah IPA Terpadu dalam Pembelajaran

3. Efektifitas hasil perkuliahan dengan menggunakan pendekatan saintifik untuk meningkatkan kemapuan berfikir kritis mahasiswa pada mata kuliah IPA Terpadu dalam Pembelajaran.

Pendekatan saintifik merupakan salah satu jalan untuk menyampaikan materi pada pembelajaran IPA terpadu agar materi tersebut dapat dinternalisasikan lebih baik lagi.

Berdasarkan hasil penelitian, tim peneliti menyarankan kepada civitas akademika pendidikan IPA bahwa pendekatan saintifik merupakan salah satu alternatif yang dapat digunakan untuk meningkatkan kemampuan berfikir kritis mahasiswa.

Kegiatan penelitian ini dapat dilanjutkan pada mata kuliah Strategi Pembelajaran IPA karena di dalam pembelajaran mata kuliah tersebut, mahasiswa diharapkan mampu menganalisis materi yang ada pada mata kuliah IPA terpadu dan mengaplikasikan materi tersebut dengan menjalankan strategi pembelajarannya sesuai dengan konten yang telah dipelajari pada semester ini.

\section{DAFTAR PUSTAKA}

Abidin, Y. (2014). Desain Sistem Pembelajaran dalam Kontekss Kurikulum 2013.

Bandung: PT Refika Aditama

Arikunto, S. (2010). Prosedur Penelitian. Jakarta: Rineka Cipta.

Arikunto, S. (2006). Prosedur Penelitian Suatu Pendekatan Praktik. Jakarta: Rineka Cipta.

Asrori, M. (2007). Penelitian Tindakan Kelas. Bandung; CV Wacana Prima.

Brown, A. L., \& Campione, J. C. (1994). Guided discovery in a community of learners. In K. McGilly (Ed.), Classroom lessons: Integrating cognitive theory and classroom practice (pp. 229-270). Cambridge, MA: MIT Press.

Cromley, J., \& Azevedo, R. (2005). What do reading tutors do? A naturalistic study of more and less experienced tutors in reading. Discourse Processes, 40(2), 83-113.

Daryanto. (2014). Pendekatan Pembelajaran Saintifik Kurikulum 2013. Yogyakarta: Gava Media.

Dinsi, M., (2014). Penerapan Pendekatan Saintifike Untuk Meningkatkan Aktivitas Dan Hasil Belajar Matematika Siswa Kelas V Sd Negeri 113 Bengkulu Selatan. Bengkulu: PPG Universitas Bengkulu (skripsi).

Engin, M. (2013). Questioning to scaffold: an exploration of questions in pre- service teacher training feedback sessions. European Journal of Teacher Education, 36(1), $39-54$

Elfira, R. (2015). Penerapan Model Pembelajaran Problem Based Learning (Pbl) Untuke Meningkatkan Kemampuan Berpikir Kritis Dan Prestasi Belajar. Bengkulu: FKIP-TP Universitas Bengkulu (tesis).

Fisher, A. (2008). Berpikir Kritis: Sebuah Pengantar. Jakarta: Erlangga.

Gunawan, A.W. (2003). Genius Learning Strategy Petunjuk Praktis untuk Menerapkan Accelarated Learning. Jakarta: Gramedia Pustaka Utama. 
Hammond, J. \& P. Gibbons. (2005). Putting scaffolding to work: The contribution of scaffolding in articulating ESL education. Prospect, 20, 6-30.

Hosnan, M. (2014). Pendekatan Saintifik dan Kontekstual dalam Pembelajaran Abad 21. Bogor: Ghalia Indonesia.

Hosnan, M. (2014). Pendekatan Saintifik dan Kontekstual Dalam Pembelajaran Abad 21. Bogor: Ghalia Indonesia

Hassoubah, Z. I. (2004). Develoving Creative \& Critical Thinking Skills (Cara Berpikir Kreatif dan Kritis). Bandung: Yayasan Nuansa Cendekia.

Kurinasih, I. \& Sani, B. (2014). Sukses Mengimplementasikan Kurikulum 2013. Kata Pena.

Kusumah, R. G. T., \& Munandar, A. (2017). ANALYSIS OF THE RELATIONSHIP BETWEEN SELF EFFICACY AND HEALTHY LIVING CONCIOUSNESS TOWARD SCIENCE LEARNING OUTCOME. EDUS AINS, 9(2), 132-138. https://doi.org/10.15408/ES.V9I2.2183

Mackiewicz, J., \& Thompson, I. (2013). Motivational scaffolding, politeness, and writing center tutoring. Writing Center Journal, 33(1), 38-73.

Mercer, N. (1995). The guided construction of knowledge: Talk amongst teachers and learners. Clevedon: Multilingual Matters Ltd.

Mercer, N. \& K. Littleton. (2007). Dialogue and the development of children's thinking. London: Routledge.

Morcom, V. (2016). Scaffolding Peer Collaboration through Values Education: Social and Reflective Practices from a Primary Classroom. Australian Journal of Teacher Education,41 (1), 81-99

Myhill, D. \& P. Warren. (2005). Scaffolds or straitjackets? Critical moments in classroom discourse. Educational Review, 57(1), 55-69

Nordlof, J. (2014). Vygotsky, Scaffolding, and the Role of Theory in Writing Center Work. The Writing Center Journal, 34 (1), 45-64
Puntambekar, S., \& Hübscher, R. (2005). Tools for scaffolding students in a complex learning environment What have we gained and

Rahmat. (2010). Pengukuran Ketrampilan Berpikir Kritis. Jakarta: PT Rineka Cipta.

Rahmat, A. (2015). Penerapan Pendekatan Saintifik Untuk Meningkatkan Kemandirian Dan Prestasi Belajar Siswa (Studi Pada Mata Pelajaran Ipa Kelas Iv Sd Negeri 14 Ketahun Kabupaten Bengkulu Utara). Bengkulu: FKIP-TP Universitas Bengkulu (tesis).

Rahmi, F. (2017). Penerapan Pendekatan Saintifik Sebagai Upaya Meningkatkan Hasil Belajar IPA Siswa Kelas IV SDN 19 Koto Tinggi. Jakarta : Jurnal Inovasi Pendidikan dan Pembelajaran Sekolah Dasar, 1 (2), 1-15.

Reiser, B. J. (2004). Scaffolding Complex Learning: The Mechanisms of Structuring and Problematizing Student Work. The Journal Of The Learning Sciences, 13(3), 273304

Rusindrayanti, \& Santoso, R. H. (2015). Implementasi Pendekatan Saintifik Mapel Matematika Kelas VII Tahun Pelajaran 2013/2014 pada Kurikulum 2013 DIY. PYTHAGORAS: Jurnal Pendidikan Matematika. 10 (1), 80-94.

Said, I.M., Sutadji, E., Sugandi, M. (2016). The Scientific Approach-Based Cooperative Learning Tool for Vocational Students Vocation Program of Autotronic (Automotive Electronic) Engineering. IOSR Journal of Research \& Method in Education,6 (3), 67-73

Susanti, (2015). Penerapan Pembelajaran Tematik Terpadu Dengan Pendekatan Saintifik Untuk Meningkatkan Aktivitas Dan Hasil Belajar. Bengkulu: FKIP-TP Universitas Bengkulu (tesis).

Wardhani,I.G.A.K. (2003). Penelitian Tindakan Kelas. Jakarta: Universitas Terbuka.

Webb, N. M., \& Palincsar, A. S. (1996). Group processes in the classroom. In D. C. Berliner \& R. C. Calfee (Eds.), Handbook of 
educational psychology (pp. 841-873). New York: Macmillan.

Wells, G. (1999). Dialogic Inquiry: Towards a Sociocultural Practice and Theory of Education. New York: Cambridge University Press.

Wijaya, A. (1995). Melatih Anak Berpikir Analitis, Kritis, dan Kreatif. Jakarta: PT Gramedia Widiasarana Indonesia.
Zafri, Berpikir Kritis Pembelajaran Sejarah. Padang. Jurnal Diakronika FIS UNP. 24 Mei 2012.

Zurek, A., Torquati., \& Acar, I. (2014).Scaffolding as a Tool for Environmental Education in Early Childhood. International Journal of Early Childhood Environmental Education, 2(1), 2757 what have we missed? Educational Psychologist, 40(1), 1-12 